\title{
Consumer Engagement with Self-expressive Brands: Brand Love and WOM Outcomes
}

\author{
Elaine Wallace* \\ Senior Lecturer in Marketing \\ J. E. Cairnes School of Business \& Economics \\ National University of Ireland Galway \\ Ireland \\ Tel: +353-91-492603 \\ Email: elaine.wallace@nuigalway.ie \\ Isabel Buil \\ Senior Lecturer in Marketing \\ Department of Marketing Management \\ University of Zaragoza \\ Spain \\ Tel: +34-976-761-000 \\ Email: ibuil@unizar.es \\ Leslie de Chernatony \\ Honorary Professor of Brand Marketing \\ Aston Business School, \\ Birmingham, \\ UK \\ Email: dechernatony@btinternet.com
}

Paper accepted for publication in Journal of Product and Brand Management

* Author for Correspondence

Acknowledgements: The authors wish to acknowledge the financial support of the Research Development Initiative, Strand 2 (Ref: RCS 258) from the Irish Research Council for the Humanities and Social Sciences, the I+D+I project (Ref: ECO2009-08283) from the Government of Spain, and the project GENERES (Ref: S-09) from the Government of Aragon and the European Social Fund. 


\section{Author Biogs:}

Elaine Wallace

Dr. Elaine Wallace is a Senior Lecturer in Marketing at the J.E. Cairnes School of Business \& Economics, National University of Ireland Galway. Elaine completed her doctorate at the University of Birmingham, working with Professor de Chernatony. She has published her work in international journals and presented at national and international conferences. Her research has been supported in part by funding from the Irish Research Council.

\section{Isabel Buil}

Dr. Isabel Buil is a Senior Lecturer in the Department of Marketing Management at the University of Zaragoza, Spain. She holds a PhD in Business Administration. She has been a Visiting Scholar at Aston Business School and Birmingham Business School, England. Isabel is a member of the research group Generes recognised by the Government of Aragon. She has published research papers in both local and international journals. She has attended and presented research papers to national and international conferences.

\section{Leslie de Chernatony}

Leslie is Honorary Professor of Brand Marketing at Aston Business School, Birmingham UK and Managing Partner at Brands Box Marketing \& Research Consultancy. His research is globally disseminated through his books (e.g. From Brand Vision to Brand Evaluation, Creating Powerful Brands, etc) frequent international conference presentations and a significant stream of international journal articles, some of which have won best paper prizes. Leslie is a Fellow of the Chartered Institute of Marketing and a Fellow of the Market Research Society.. He has run many highly acclaimed branding workshops globally. His advice has been sought by organisations throughout the world on developing more effective brand strategies. On several occasions he has acted as an Expert Witness in court cases over branding issues. 


\title{
Consumer Engagement with Self-expressive Brands: Brand Love and WOM Outcomes
}

\begin{abstract}
Purpose: This study explores attitudes of consumers who engage with brands through Facebook 'Likes'. It explores the extent to which these brands are self-expressive and examines the relationship between brand 'Liking' and brand outcomes. Brand outcomes include brand love and advocacy, where advocacy incorporates WOM and brand acceptance.

Design/methodology/approach: Findings are presented from a survey of 265 Facebook users who engage with a brand by 'Liking' it.

Findings: Brands 'Liked' are expressive of the inner or social self. The study identifies a positive relationship between the self-expressive nature of brands 'Liked' and brand love. Consumers who engage with inner self-expressive brands are more likely to offer WOM for that brand. By contrast, consumers who engage with socially self-expressive brands are more likely to accept wrongdoing from a brand.
\end{abstract}

Research Limitations: The research is exploratory and is limited to consumers who are engaged with a brand through 'Liking' it on the Facebook social network.

Practical Implications: The study offers suggestions for managers seeking to enhance brand engagement through Facebook 'Liking', and to encourage positive brand outcomes (such as WOM) among consumers already engaged with a brand on Facebook.

Originality: This paper provides new insights into consumer brand engagement evidenced through Facebook 'Liking'. It charts the relationship between 'Liked' self-expressive brands and brand love. Distinctions are drawn between brand outcomes among consumers who 'Like’ for socially self-expressive reasons, and consumers who are brand engaged by 'Liking' to express their inner selves. 
Keywords: Brand Engagement, Facebook, Brand Love, Self-Expressive Brands, WOM, Advocacy

\section{Research Paper}




\section{Introduction}

Brand engagement is a composite of experiential and social dimensions (Gambetti et al., 2012). It is defined as 'the level of an individual customer's motivational, brand-related and context-dependent state of mind characterised by specific levels of cognitive, emotional and behavioural activity in direct brand interactions' (Hollebeek, 2011, p. 790). This study focuses on the ‘social dimension’ of brand engagement (Gambetti et al., 2012, p. 681).

This study examines brand engagement on Facebook. As Malhotra et al. (2013, p. 18) note 'brands have embraced Facebook as a key marketing channel to drive engagement and brand awareness'. On Facebook, number of 'Likes', shares, or comments a brand's page receives is a manifest variable for brand engagement (Chauhan and Pillai, 2013; Hoffman and Fodor, 2010; Malhotra et al., 2013). Consumers who click 'Like' are more engaged, active and connected than the average Facebook user (Facebook, 2010). Moreover, recent BrandZ data suggests that those who 'Like' brands spend up to five times as much money on their 'Liked' brand, than those who do not 'Like' those brands, with a $13.4 \%$ share of wallet among fans of the 'Liked' brand, compared with a 2.8\% share among non-fans (Hollis, 2011). In addition, the brands engaged on Facebook have greater potential to influence others: those who 'Like' tend to have 2.4 times as many friends on their Facebook network as other users, and they are likely to click on 5.3 times more links than other Facebook users (Nelson-Field et al., 2012). Therefore, fans are more connected, and can better facilitate the spread of brand messages across their social networks, than non-fans. Clearly, gaining insights from Facebook fans provides new and valuable insights into consumers' brand engagement.

The extant literature examining brand engagement in an offline context has identified relationships between brand engagement, brand love and consumers' use of brands to enhance self-expression of identity (see for example Bergkvist and Bech-Larsen, 2010). Yet little is known about the relationship between a consumer's brand 'Likes' on a social network, and 
their behaviours in relation to that brand. This study explores whether brand engagement, evidenced through 'Liking', is associated with the use of self-expressive brands, and brand love, in the virtual environment of the social network. While traditional perspectives of brand engagement are grounded in the relationship paradigm (e.g. Grönroos, 2007), this study seeks to understand engagement in an environment where there is an immediacy to the act of 'Liking', where brands are 'consumed', at least in part, for self-presentation, and the brand may exist outside the material reality of the consumer (Schau and Gilly, 2003). Further, this study draws on Carroll and Ahuvia's (2006) research to examine whether their posited relationship between such brand relationships and WOM is also evident in a social network context.

The paper opens with a literature review. It describes the methodology, reports the empirical findings, and discusses their implications. Finally, it addresses the limitations of the study and identifies directions for further research.

\section{Brand engagement on the social network: self-expressive brands on Facebook}

While researchers are advancing knowledge about brand engagement, social networks continue to present challenges. For example, the relational structure of the network influences consumer communication as companies lose control of the brand message and it is co-created among network members (Kozinets et al., 2010). It is understood that the linking value of networks enables consumers to engage with a community (Muniz and O’Guinn, 2001). It is therefore feasible that consumers connect with brands to interact with others on that brand's network - rather than to connect with the brand.

Recently, practitioners and academics have suggested that, on social networks, 'Likes' provide insights about engagement (Kalpana and Anandan, 2013). Hoffman and Fodor (2010, p. 46) distinguish between strategies crafted to create brand engagement on social 
networks (for example 'blogs with podcasts, videos and other social media tools'), and the metrics best employed to assess a brand's social media performance. They argue that an appropriate metric for brand engagement on social networks is the number of 'Likes' a brand achieves on a friend's feeds (Hoffman and Fodor, 2010). Therefore, this study explores 'Likes' on Facebook, asserting that 'Liking' brands is a manifestation of brand engagement.

Facebook allows consumers to interact with brands, and also with others who share the same brand preferences (Hollenbeck and Zinkhan, 2006). On Facebook, self-identity is created through consumers' descriptions of themselves, and how they connect to others within a network (Schau and Gilly, 2003). Consumers who select 'Like' for a brand may do so to allow that brand to express their ideal or actual selves (Ahuvia, 2005). We draw on Sprott et al. (2009) who considered the role of brand engagement in the self-concept, as consumers' propensity to include brands as part of how they view themselves.

On Facebook, consumers engaging with brands, state they 'Like' them to build part of their online self-expression (Lipsman et al., 2012; Trusov et al., 2009). Such self-expressive brands are defined as 'the customers' perception of the degree to which the specific brand enhances one’s social self and/or reflects one’s inner self' (Carroll and Ahuvia 2006, p. 82). Social networks allow consumers to present an 'ideal self' and therefore, consumers may choose brands to express a self that is not supported in their material world (Schau and Gilly, 2003). This study offers a contribution to the extant research as it considers the selfexpressive nature of the brand when the brand is 'Liked' on online social networks. Further, we advance the research of Carroll and Ahuvia (2006) as we consider the relationship between self-expressive brands and the outcomes brand love and WOM, on the social network. We assert that the social network is not merely an alternative context for this study: rather we consider the unique opportunities presented by the network for self-expression (Kozinets et al., 2010; Schau and Gilly, 2003). We are cognisant of the emerging perspective 
that brand engagement includes a social dimension encompassing interaction, participation, co-creation and sharing of brand-related contents (Gambetti et al., 2012, p. 5), and the accepted view that consumers have a propensity to include brands in their self-concept (Sprott et al., 2009).

Furthermore, the variables brand love and WOM have relevance for our study. The association between brand love and 'active engagement' has been identified in the literature (Bergkvist and Bech-Larsen, 2010). This identified 'activist' consumers, i.e. those individuals who are highly engaged (Hollebeek, 2011). Brand engagement has also been positively associated with positive WOM (Tripathi, 2009). This study therefore considers the relationship between consumers' brand engagement through 'Liking' self-expressive brands, and the outcomes brand love and WOM. This paper next conceptualises the concepts of brand love and WOM.

\section{Brand love}

As individuals have different self-schemas, consumers display different attitudes towards objects which shape those schemas, including engagement with brands that shape their self-concept (Sprott et al., 2009). Brands that shape consumers' identity result in more powerful emotional responses (Carroll and Ahuvia, 2006). Consumer responses to brands encompass, amongst other things, loyalty (Jacoby and Chestnut, 1978), attachment (Thomson et al., 2005), and brand love (Ahuvia, 2005; Albert et al., 2008; Batra et al., 2011; Fournier 1998). We seek to understand the relationship between consumer engagement through brand 'Liking' on Facebook and consumers' brand love and WOM.

Brand love is defined as the 'degree of passionate emotional attachment a satisfied customer has for a particular trade name’' (Carroll and Ahuvia, 2006, p. 81). Fournier (1998, p. 363) found that 'at the core of all brand relationships was a rich affective grounding 
reminiscent of the concepts of love in the interpersonal domain'. Her study of consumer brand relationships suggested consumers experienced passion, obsession and dependency on particular brands, and a feeling 'something was missing' (Fournier, 1998, p. 364) when the brand was not used. The application of interpersonal theory of love to the product concept remains contested in the literature (Albert et al., 2008; Batra et al., 2011). Albert et al. (2008) suggest that human love emotions become liking, yearning and commitment within a consumption context. Yet passion remains: Ahuvia (2005) suggests that love exists when desire for the product reaches or extends beyond a threshold. Although there are some differences in the conceptualisation of brand love in the literature, studies are consistent in their assertion that self-brand integration is a construct of brand love. Just as human couples share similar values and humour, congruity between self-image and product image enhances brand love (Albert et al., 2008).

Thus, consumers may love a brand due to 'self-image motives and self-esteem motives’ (Albert et al., 2008, p. 73). Specifically, Carroll and Ahuvia (2006) found that selfexpressive brands had a positive effect on brand love. Furthermore, in a study of young people, Hwang and Kandampully (2012) found that self-concept connection increases brand love. In this study the brand is the 'Liked' brand on Facebook, as 'Liking' brands is a proxy measure for brand engagement (Hoffman and Fodor, 2010). As consumers vary in their level of brand engagement, partly due to their perceptions about the self-expressive role of the brand (Sprott et al., 2009), this study investigates the extent to which brands 'Liked' on Facebook are self-expressive. We note that Batra et al.’s (2011) most recent conceptualisation of brand love encompasses consumers' use of the brand to express both current and desired self-identity. If the brand 'Liked' facilitates the consumer's self-expression, they may experience greater brand love. It is therefore hypothesised: 
H1: There is a positive relationship between self-expressive brands Liked on Facebook and brand love.

\section{Brand WOM and brand acceptance}

The literature suggests that consumers who are highly engaged with a brand are activists for that brand (Hollebeek, 2011). Bergkvist and Bech-Larsen's (2010) study suggested that consumers who had a sense of community and strong brand identification experience more brand love and active engagement. Bergkvist and Bech-Larsen (2010, p. 510) incorporate word of mouth (WOM) in their measure of active engagement. In this study, engaged consumers on social networks are considered as potential brand activists. The social network supports advocacy, because of the influence of online members (Lawler and Knox, 2006). In addition to connecting with others, these individuals may have emotional bonds with a brand and participate with the brand through high involvement and positive WOM (Wragg, 2004). WOM is the flow of communication among consumers about products or services (Westbrook, 1987). In addition to offering brand recommendations to others, it is asserted that brand advocates are also likely to accept new brand extensions and to forgive a brand for wrongdoing (Du et al., 2007). Although advocacy, incorporating WOM and brand acceptance, can originate from multiple sources, including friends or experts (Senecal and Nantel, 2004), this study explores the brand WOM and acceptance of consumers who engage with brands on Facebook by 'Liking' them.

Kozinets et al. (2010) explain that social networks have transformed word of mouth theory, because consumers spread comments not only to reduce dissonance or because of altruistic desires to help others, but also because the customer is now an actor in a social system. The motivation to engage in online WOM is therefore a form of 'keeping up with the 
Jones’ (Iyengar et al., 2009, p. 1), as consumers seek to influence others about their brand choices, and in so doing, to express themselves through those choices.

Consumers who 'Like' a brand on a social network such as Facebook may do so as part of impression management (Schau and Gilly, 2003). For example, a consumer may 'Like' the Chanel brand to benefit from its brand associations such as sophistication and glamour. Yet the Chanel brand may not align with the consumer's material world (Schau and Gilly, 2003). It is questioned whether WOM on social networks reflects a 'true' engagement with the brand. It is possible that consumers derive further benefits from the brand by offering WOM. De Angelis et al. (2012) note that consumers seeking self-enhancement are more likely to link the self to positive outcomes. In offline experiments, they found that the fundamental motive to enhance the self leads consumers to generate WOM (De Angelis et al., 2012). As consumers may 'Like' brands as a form of self-enhancement (Schau and Gilly, 2003), this study investigates whether the self-expressive nature of these 'Likes' translates into positive WOM and brand acceptance. Therefore, it is postulated:

H2: There is a positive relationship between self-expressive brands Liked on Facebook and WOM.

H3: There is a positive relationship between self-expressive brands Liked on Facebook and brand acceptance.

Previous studies found that brand love is positively associated with WOM (Carroll and Ahuvia, 2006), since brand love predicts active engagement (Bergkvist and Bech-Larsen, 2010). In a related study, Matzler et al. (2007, p. 27) found a significant positive relationship between brand passion and 'evangelism', where evangelism extends beyond WOM to include active spreading of positive opinion and trying to persuade others to become engaged with the 
same brand. While some literature considers the function of advocacy as customer acquisition (for example Samson, 2006), this study adopts Du et al.'s (2007) definition of advocacy as trying new products from the brand, talking up the brand, and a willingness to accept wrongdoing by the brand. This interpretation of advocacy is wise as advocacy in this context includes forgiveness for wrongdoing. The literature suggests that brand love has been found to explain variation in consumers' 'positive WOM and resistance to negative information about the brand' (Batra et al. 2011, p. 2), therefore a measure of brand advocacy that considers resistance to negative information has relevance. This study seeks to better understand brand engagement on social networks, by exploring the outcomes of consumers’ 'Liking' self-expressive brands. Therefore the study questions whether those consumers who love the brands they 'Like' are more likely to become advocates for those brands. Furthermore, Fournier (1998, p. 364) asserted that 'feelings of love encouraged a biased positive perception' of the brand, and stronger affective ties facilitated accommodation for wrongdoing by the brand, or biased attributions of blame. Therefore, it is appropriate to consider the relationship between brand love and brand advocacy, where advocacy includes acceptance of wrongdoing. As such it is postulated:

H4: There is a positive relationship between loved brands Liked on Facebook and WOM.

H5: There is a positive relationship between loved brands Liked on Facebook and brand acceptance.

\section{Research method}

Facebook users' views were elicited through a web-based survey at an Irish University. Students are uniquely poised to help researchers understand the social network (Gallagher et al., 2001). Designed for use by college students (Hunt et al., 2012), Facebook is 
popular among students. For example, 96\% of students in the US use Facebook (Education Database Online, 2011). Facebook acts as a digital public space where young consumers can connect virtually, and its popularity among this age cohort in part reflects younger consumers' motivations to gain attention from others (Bowley, 2006). Moreover, previous studies of Facebook users utilised student populations (e.g. Hunt et al., 2012; Lewis et al., 2008; Patterson, 2011). Further, student samples have relevance for the constructs of the study. For example, Batra et al.’s (2011) study on brand love was conducted, in part, among college students.

Following a pilot test with 15 Facebook users, students were surveyed using the SurveyMonkey online survey-hosting site. To offer reassurances of credibility, the survey was incorporated as a link circulated via email by the University Students’ Union. Students clicked on the link, and responded to the survey directly. To encourage responses, prizes of four $€ 50$ vouchers for University catering services were offered as an incentive.

265 complete responses were received. A profile of respondents is presented in Table 1. As the literature considers 'Likes' as a manifest variable of brand engagement on social networks (Chauhan and Pillai, 2013; Hoffman and Fodor, 2010; Malhotra et al., 2013), respondents were asked to identify a brand they 'Liked' on Facebook. Brands 'Liked' were in the following categories: fashion brands (21\% of Likes), sportswear (13.6\%), soft drinks (7.3\%), alcohol (7\%), retailers including fast food (6.6\%), other websites (5.1\%), music, including artists and equipment (4\%), cosmetics (3.7\%) and food brands (3.3\%).

Place Table 1 about here.

Students were asked to think about their 'Liked' brand when responding to questions, using 5-point Likert scales (see Appendix I). Carroll and Ahuvia’s (2006) WOM study 
informed the self-expressive brand measures, and brand love measures. Measures of brand advocacy, which incorporates WOM and brand acceptance, were adapted from Carroll and Ahuvia (2006) and Du et al. (2007).

\section{Findings}

The proposed model was examined using structural equation modelling (SEM). The data was analysed using SPSS 19 and EQS 6.1. A two-step structural equation modelling approach was followed. First, the psychometric properties of the scales used in the study were examined. Second, the structural model was evaluated by testing the hypotheses.

In the first stage, scales were evaluated using exploratory and confirmatory techniques to assess reliability, dimensionality and validity. In the exploratory factor analyses, selfexpressive brand was confirmed as a multidimensional construct, consisting of two factors: inner and social self, consistent with Carroll and Ahuvia (2006). The two-factor structure accounted for $86.25 \%$ of the variance explained. Similarly, brand advocacy was found to be multidimensional, with two factors: WOM and brand acceptance, in line with Carroll and Ahuvia (2006) and Du et al. (2007). The resulting factor structure accounted for $73.25 \%$ of the variance explained. Finally, brand love provided a single factor structure, accounting for $79.50 \%$ of the variance explained. Scale reliability for all items was assured as Cronbach's Alpha measures were greater than 0.7 for each of the factors.

Confirmatory factor analysis (CFA) using the robust maximum-likelihood estimation method was next performed (see Appendix I). Results suggested the deletion of 2 items in the brand love construct with their standardised parameter estimates less than 0.5 , indicating weak factor loadings. CFA produced an acceptable fit to the data: S-B $\chi^{2}(220)=494.591$, $\mathrm{p}<0.001, \mathrm{NNFI}=0.940, \mathrm{NFI}=0.911, \mathrm{CFI}=0.948, \mathrm{IFI}=0.948, \mathrm{RMSEA}=0.069$. All factor loadings were above 0.5 and statistically significant which suggested the convergent validity 
of factors. The average variance extracted (AVE) and composite reliability (CR) values were greater than 0.5 and 0.7 , ranging from 0.561 to 0.842 and from 0.718 to 0.963 respectively. Discriminant validity was also supported. As such, the AVE for any two constructs was always greater than the square of the correlation estimate (see Appendix II).

In the second stage, hypotheses were tested using again the robust maximumlikelihood estimation method. It is important to note that our conceptual framework posited self-expressive construct as a single variable. However, our analysis, as noted earlier, suggested a two-factor structure for self-expressive brand (inner self and social self). Therefore, in presenting the results in Table 2, we distinguish between SEI (self-expressive inner self) and SES (self-expressive social self). That is, Hypothesis 1 is split into two hypotheses, were Hypothesis 1a addresses the relationship between self-expressive brand that reflect the social self and brand love, and Hypothesis 1b addresses the relationship between self-expressive brand that reflect the inner self and brand love. Similarly, Hypothesis 2 is split into two hypotheses with Hypothesis 2a addressing the relationship between self-expressive brand that reflect the social self and WOM, and Hypothesis 2b addressing the relationship between self-expressive brand that reflect the inner self and WOM. Finally, Hypothesis 3 is also split into two hypotheses with Hypothesis 3a addressing the relationship between selfexpressive brand that reflect the social self and brand acceptance, and Hypothesis 3b addressing the relationship between self-expressive brand that reflect the inner self and brand acceptance. The results of all hypotheses tests are summarised in Figure 1.

Place Table 2 about here.

Place Figure 1 about here. 
The results reveal some interesting findings. Respondents 'Liking' chose brands that were self-expressive. This finding is consistent with the literature that suggests that engaged consumers associate with brands that fit their self-concept (Sprott et al., 2009). When consumers engage with the brand by 'Liking' it, this brand appears in their news feed of their social network. As the brands 'Liked' are self-expressive, the brand is allowing the consumer to enhance their identity in their social exchanges with others on Facebook.

Further, both of self-expressive brands, inner and social, are positively associated with brand love. Therefore hypothesis H1 was supported. Hypothesis H2 posited a positive association between the self-expressive nature of a brand 'Liked' on Facebook, and the likelihood of offering positive worth of mouth. In the case of self-expressive brands that reflect the social selves, this relationship was not statistically supported (H2a). By contrast, findings indicated a positive association between self-expressive brands 'Liked' that reflect the inner selves and WOM, as the coefficient is positive and significant (H2b). Therefore, hypothesis H2 was partially supported. Similarly, the relationship between the selfexpressive nature of a brand 'Liked' on Facebook, and the likelihood of accepting a brand is different for those brands reflecting the inner and the social self. Results show that those consumers who 'Like' brands that reflect their social self, are more likely to accept the brand (H3a). By contrast, for those brands that reflect the inner self-identity, the relationship was not significant (H3b). Therefore, hypothesis H3 was partially supported. Finally, hypotheses H4 and H5 are supported, meaning that brand love is positively associated with worth of mouth and brand acceptance. These findings are discussed in detail in the following section.

\section{Discussion}

The literature suggests that consumers develop self-schemas about brands they use or like (Sprott et al., 2009), and such brand 'Liking' on the social network is a manifestation of 
consumers' engagement (Chauhan and Pillai, 2013). This study provides new insights into consumers' brand engagement with self-expressive brands by exploring those brands 'Liked' on the Facebook social network. To the authors' knowledge, it is the first study of its kind to explore brand engagement by eliciting the views of Facebook fans, and examining the extent to which those brands 'Liked' are socially self-expressive (expressing the social self), or inner self-expressive (expressing the true self), and the outcomes of this relationship for brand love and WOM. This contribution is broader than mere context, as, on the social network, consumers can 'Like’ brands that are outside of their material reality (Schau and Gilly, 2003). Therefore, the findings provide new insights into brand engagement, where the brand is in a virtual space, and may not be owned by the 'Liker', but rather used to construct the self identity.

This study reveals that there is a positive relationship between 'Liked' brands that are self-expressive, and brand love. We show that brands that allow fans to express themselves on Facebook are more likely to love those brands. Further, we find that when consumers engage with self-expressive brands online, brand love mediates the relationship between those brands and WOM.

Cognisant that consumers are likely to engage with brands that reflect their selfconcept (Sprott et al., 2009), the study provides new insights into the role of the brand in selfexpression, by distinguishing between self-expressive brands (social self) and self-expressive brands (inner self) (Carroll and Ahuvia, 2006). In our study, both forms of self-expressive brands are positively associated with greater brand love. These findings add new support for Batra et al.'s (2011) study of the components of brand love, within the context of the online social network. Batra et al. (2011) assert that loved brands allow consumers to express who they truly are, or to reflect who they want to be. Although their assertions related to brands in an offline context, our findings show that brands play a similar role on the social network, as 
brands that allow self-expression achieve greater brand love. Furthermore, findings support Bergkvist and Bech-Larsen's (2010) assertion that brand identification is an antecedent of brand love.

Among the respondents in this study, the relationship between 'Liking' self-expressive brands that reflect their social selves and WOM was not significant. However, there was a positive and significant relationship between 'Liking' self-expressive brands that reflect the inner self and WOM. This finding presents new insights into the relationship between brand engagement and WOM. We found that consumers who engage with the brand by 'Liking' will offer WOM when they perceive a genuine congruency between the brand meaning and their self-identity (Shau and Gilly, 2003). Therefore, we suggest that brand-engaged consumers, who 'Like' their brand on Facebook, will offer WOM for that brand if the brand resonates with their inner selves. By contrast, when fans 'Like' brands that appeal to the social self, they are doing so in order to express their social selves, with no intention to actively provide any form of brand recommendation. This finding suggests that it may not be reasonable to assume all 'Likers' are the same, and would respond to a brand in the same way. We suggest that WOM could be considered as an activity that perhaps incurs cost to the consumer or requires involvement (for example, by taking time to offer a recommendation). Thus, unless a brand appeals to their inner selves, customers will not engage in WOM.

In addition to WOM, this study investigated whether consumers' brand engagement with self-expressive brands on Facebook have greater brand acceptance. Du et al. (2007) identified brand acceptance as a component of brand advocacy. Brand acceptance includes an interest in trying new products under the brand name and a willingness to accept wrongdoing by the brand (Du et al., 2007). Our findings reveal new insights as we show that consumers who 'Like' a brand that reflects their inner self will not accept wrongdoing by the brand. We assert that consumers who engage with brands that reflect their inner self-identity are likely to 
be disappointed when the brand lets them down, and therefore less accepting of wrongdoing. By contrast, when a consumer engages with a brand by 'Liking' in order to reflect their social self (Carroll and Ahuvia, 2006; Gambetti et al., 2012), they may wish to keep up appearances about the brand, refusing to accept negative stories about the brand, and willing to try new products under the same brand name.

Therefore, we contribute to extant theory about self-expressive brands. We show that there are differences in the outcomes for brands that express the inner self. For those brands, consumers will experience brand love, they will offer WOM, but they will be less likely to forgive a brand for "wrongdoing”. We assert that this is a 'real' brand relationship, where the consumer has a genuine attachment to the brand because it reflects themselves. By contrast, we show that for consumers who 'Like' brands that express a social self, consumers will experience brand love, but they are less likely to offer WOM. However, they will accept wrongdoing, arguably because the brand is not internalised and does not really resonate with the self.

Finally, when consumers engage with brands by 'Liking' on Facebook, we show that loved brands are more likely to encourage WOM. This study supports the findings of Carroll and Ahuvia (2006), who found a positive direct effect of brand love on WOM. Moreover, findings support Matzler et al.’s (2007) assertion that passionate consumers evangelise. When consumers have strong and positive emotional attachment to a brand, they are more likely to offer WOM and to advocate the brand to others (Matzler et al., 2007). Further, brand love is associated with greater brand acceptance, as consumers are more likely to try new product launches from a loved brand and are more likely to forgive a loved brand for wrongdoing (Du et al., 2007). 


\section{Managerial Implications}

The study sought to gain insights into brand engagement, by exploring the attitudes of consumers who 'Like’ brands on Facebook. Findings have implications for managers seeking to harness social networks to build brand relationships. This study distinguishes between consumers who 'Like' brands for inner self-expressive and social self-expressive reasons. Consumers in this study 'Liked' the brand for reasons of self-expression. Managers seeking to enhance the engagement with their brand on Facebook, and increase the number of 'Likes' a brand receives, should emphasise the self-expressive nature of the brand. For example, marketing communications content could encourage the consumer to 'express yourself' through association with the brand. Moreover, managers seeking to enhance interaction by engaged consumers could encourage them to share brand messages. Incentives for sharing could be effective in encouraging those who 'Like' the brand to communicate the brand message to networked friends.

Brand-engaged consumers who 'Like' self-expressive brands differ in their brand advocacy, depending on the self-expressive role of the brand. To increase WOM, managers should target consumers with messages that appeal to the inner self. For example, companies may employ a colleague to seed posts on a brand's Facebook page, to reinforce authenticity for the brand. Consumers who 'Like' the brand receive such comments in their news feed. If the consumer receives such brand updates, this enhances their perceptions of authenticity and reinforces the belief that the brand is intrinsic to their self-concept, encouraging further WOM.

If consumers engage with a brand by 'Liking' to enhance their social selves, they are less likely to offer WOM. Managers wishing to enhance WOM through Facebook can reward such customers for offering WOM, encouraging them to connect to their network and spread positive messages about the brand. For example, brand managers may hold Facebook 
competitions to reward the best endorser of the brand. These consumers may be motivated by popularity. Therefore managers could hold competitions to reward consumers who achieve the greatest number of 'Likes' among their friends' networks. Thus, the consumer's desire for social popularity facilitates further engagement through 'Likes', across the social network.

When consumers engage with a brand by 'Liking' it on Facebook, there is a further distinction between consumer types. Consumers who are brand engaged and believe that the brand reflects their inner selves are less accepting of wrongdoing by the brand. The literature identifies 'activists' as those consumers with high levels of brand engagement and high levels of loyalty (Hollebeek, 2011, p. 797). It is thought that such activists may choose to work against the brand if they believe that the brand reflects them, but is guilty of wrongdoing. The linking value of the social network also supports the spread of negativity, and therefore the most engaged consumers could become a brand's worst saboteurs, through negative WOM. Managers can minimise such risks through vigilant monitoring of brand messages, in both traditional and social media.

Those consumers who engage by 'Liking' but do so for social reasons should be more likely to forgive the brand for wrongdoing. Such consumers can be harnessed as brand ambassadors for positive brand messages. Organisations experiencing difficulties with their brand image could appeal to those consumers who connect with others by talking about their brand and encourage them to offer reassurance to others. For example, brands can create virtual spaces where brand 'Likers' can connect together when a problem occurs.

\section{Limitations and further research}

Limitations in this research are acknowledged. The study is limited to students who are Facebook users. Although this population is relevant for this study, it is advocated that the research be replicated among other Facebook users, to explore the generalizability of the 
findings. Further, this study considered brand engagement as evident in consumer 'Liking'. Although this is consistent with recent theory in relation to social networks (e.g. Chauhan and Pillai, 2013; Hoffman and Fodor, 2010), other Facebook behaviours such as posting agility or number of comments could also present insights into brand engagement (Chauhan and Pillai, 2013).

In addition, understanding the motivation for 'Likes' also requires further investigation. It would be interesting to research whether consumers who engage with brands by 'Liking' to express the inner self are motivated to use Facebook for different reasons than others who may be more concerned with social acceptance. Further research could also investigate whether the Facebook member who 'Likes' brands that reflect the inner self has different characteristics to the individual who 'Likes’ brands that reflect the social self.

We earlier highlighted research by Matzler et al. (2007), which found that passionate consumers were more likely to evangelise but they may also be the strongest opponents to the brand if it disappoints them. It is not possible to overtly 'Dislike' brands on the Facebook social network as there is no 'Dislike' button, therefore this study could not capture the views of those consumers who had disengaged with the brand. However, consumers can un-'Like’ a brand. Further research could investigate the relationship between brand un-'Likes' and outcomes such as WOM. For example, it would be interesting to explore whether consumers who disengage by un-'Liking’ offer negative WOM. This may be particularly true when brands are self-expressive, as the consumer may perceive a disconnect between the brand and the self-concept, leading them to 'un-Like' the brand, and spread negative WOM, in the social sphere of the social network. 


\section{Conclusion}

This study sought to understand consumers' relationships with brands 'Liked' on Facebook. As 'Liking' is an expression of brand engagement, and consumers engage with brands that support the self-concept, this study investigated the extent to which 'Liked' brands are inner or socially self-expressive. The relationship between both forms of selfexpressive brands 'Liked' and brand love was identified. Further, this study considered whether 'Liking' such self-expressive brands enhanced WOM or brand acceptance, and explored whether such advocacy outcomes were influenced by brand love. It was reported that consumers who engage with self-expressive brands through 'Liking' have high levels of brand love. Yet those consumers who engage with inner self-expressive brands will be more likely to offer WOM. By contrast, consumers who engage with social self-expressive brands will be more likely to accept brand wrongdoing. We hope that our findings provide a helpful starting point for future research, and prompt managers to build more effective brand engagement through Facebook. 


\section{References}

Ahuvia, A.C. (2005), “Beyond the extended self: Loved objects and consumers' identity narratives”, Journal of Consumer Research, Vol. 32 No. 1, pp. 171-184.

Albert, N., Merunka, E. and Valette-Florence P. (2008), "When consumers love their brands: exploring the concept and its dimensions”, Journal of Business Research, Vol. 61 No. 10, pp. 1062-1075.

Batra, R., Ahuvia, A. and Bagozzi. R. (2011), “Brand Love”, Journal of Marketing, Vol. 76, pp. 1-16.

Bergkvist, L. and Bech-Larsen, T. (2010), “Two studies of consequences and actionable antecedents of brand love”, Brand Management, Vol. 17 No. 7, pp. 504-518.

Bowley, G. (2006), “The high priestess of internet friendship”, Financial Times. October 27th, available at http:/www.ft.com/intl/cms/s/0/59ab33da-64c4-11db-90fd0000779e2340.html\#axzz26Ae9oMDu (accessed 27 May 2013).

Carroll, B.A. and Ahuvia, A.C. (2006), "Some antecedents and outcomes of brand love”, Marketing Letters, Vol. 17, pp. 79-89.

Chauhan, K. and Pillai, A. (2013), "Role of content strategy in social media brand communities: a case of higher education institutes in India”, Journal of Product and Brand Management, Vol. 22 No. 1, pp. 40-51.

De Angelis, M., Bonezzi, A., Peluso, A.M., Rucker, D.D. and Costabile, M. (2012), “On Braggarts and gossips: a self-enhancement account of word-of-mouth generation and transmission”, Journal of Marketing Research, Vol. XLIX (August), pp. 551-563.

Du, S., Bhattacharya, C.B. and Sen, S. (2007), "Reaping relational rewards from corporate social responsibility: the role of competitive positioning” International Journal of Research in Marketing, Vol. 24 No. 3, pp. 224-241. 
Education Database Online (2011). “Is social media ruining students?” available at http://www.onlineeducation.net/2011/04/21/is-social-media-ruining-students (accessed 27 May 2013).

Facebook (2010), "The Value of a Liker" Available at http://www.facebook.com/note.php?note_id=150630338305797 (accessed 4 October, 2013).

Fournier, S. (1998), "Consumers and their brands: Developing relationship theory in consumer research”, Journal of Consumer Research, Vol. 24 No. 4, pp. 343-373.

Gallagher, K., Foster, K.D. and Parsons, J. (2001), “The medium is not the message: Advertising effectiveness and content evaluation in print and on the web", Journal of Advertising Research, Vol. 41 No. 4, pp. 57-70.

Gambetti, R.C., Graffigna, G. and Biraghi, S. (2012), “The Grounded Theory approach to consumer-brand engagement: the practitioner's standpoint”, International Journal of Market Research, Vol. 54 No. 5, pp. 659-687.

Grönroos, C. (2007), In Search of a New Logic of Marketing: Foundations of Contemporary Theory, John Wiley, Hoboken NJ.

Hoffman, D. and Fodor, M. (2010), "Can you measure the ROI of your social media marketing?”, MIT Sloan Management Review. Vol. 52 No. 1, pp. 40-49.

Hollebeek, L.D. (2011), “Demystifying customer brand engagement: Exploring the loyalty nexus”, Journal of Marketing Management, Vol. 27 Nos. 7-8 (July), pp. 785-807.

Hollenbeck, C.R. and Zinkhan, G.M. (2006), "Consumer activism on the Internet: the role of anti-brand communities”, Advances in Consumer Research, Vol. 33, pp. 479-485.

Hollis, N. (2011), “The Value of a Social Media Fan” in Millward Brown’s "Straight Talk”. Available at: http://www.millwardbrown.com/global/blog/Post/2011-04-04/The-valueof-a-social-media-fan.aspx (accessed 4 October, 2013). 
Hunt, D., Atkin, D. and Krishnan, A. (2012), “The influence of computer-mediated communication apprehension on motives for Facebook use”, Journal of Broadcasting and Electronic Media, Vol. 56 No. 2, pp. 187-202.

Hwang, J. and Kandampully, J. (2012), “The role of emotional aspects in younger consumer brand relationships”, Journal of Product and Brand Management, Vol. 21 No. 2, pp. 98-108.

Iyengar, R., Han, S. and Gupta, S. (2009), “Do Friends Influence Purchases in a Social Network?” Harvard Business School Marketing Unit Working Paper No. 09-123. http://ssrn.com/abstract=1392172 (accessed 27 May 2013).

Jacoby, J. and Chestnut. R.W. (1978), Brand Loyalty: Measurement and Management, John Wiley and Sons, London

Kozinets, R.V., de Valck, K, Woknicki, A.C. and Wilner, S.J.S. (2010), “Networked narratives: Understanding word of mouth marketing in online communities”, Journal of Marketing, Vol. 74 No. 2, pp. 71-89.

Lawer, C. and Knox, S. (2006), “Customer advocacy and brand development”, Journal of Product and Brand Management, Vol. 15 No. 2, pp. 121-129 .

Lewis, K., Kaufman, J., Gonzalez, M., Wimmer, A. and Christakis, N. (2008), “Tastes, ties and time: A new social network dataset using Facebook.com”, Social Networks, Vol. 30, pp. 330-342.

Lipsman, A., Mudd, G., Rich, M. and Bruich, S. (2012), “The power of 'like'. How brands reach (and influence) fans through social media marketing”, Journal of Advertising Research, March, pp. 40-52.

Malhotra, A., Malhotra, C.K. and See, A. (2013), "How to create brand engagement on Facebook”, MIT Sloan Management Review, Vol. 54 No. 2, pp. 18-20. 
Matzler, K., Pichler, E.A. and Hemetsberger, A. (2007), "Who is spreading the word? The positive influence of extraversion on consumer passion and brand evangelism”. Proceedings from the American Marketing Association Winter Educators' Conference, Marketing Theory and Applications, Volume 18, available at: http://www.marketingpower.com/Community/ARC/Gated/Documents/Connections/AR C_AMA_WINTER2007.pdf (accessed 27 May 2013).

Muniz, A.M.Jr. and O’Guinn, T.C. (2001), “Brand community”, Journal of Consumer Research, Vol. 27 No. 4, pp. 412-432.

Nelson-Field, K., Riebe, E. and Sharp, B. (2012), “What’s not to 'Like’? Can a Facebook fan base give the brand the advertising reach it needs?”, Journal of Advertising Research, Vol. 52 No. 2, pp. 262-269.

Patterson, A. (2011), "Social-networkers of the world, unite and take over: A metaintrospective perspective on the Facebook brand”, Journal of Business Research, Vol. 65 No. 4, pp. 527-534.

Samson, A. (2006), "Understanding the buzz that matters: negative versus positive word of mouth”, International Journal of Market Research, Vol. 48 No. 6, pp. 648-657.

Schau, H.J. and Gilly, M.C. (2003), "We are what we post? Self-presentation in personal web space”, Journal of Consumer Research, Vol. 30 No. 3, pp. 385-404.

Senecal, S. and Nantel, J. (2004), “The influence of online product recommendations of consumers’ online choices”, Journal of Retailing, Vol. 80, pp. 159-169.

Sprott, D., Czellar, S. and Spangenberg, E. (2009), “The importance of a general measure of brand engagement on market behavior: Development and validation of a scale”, Journal of Marketing Research, Vol. 46 No. 1, pp. 92-104. 
Thomson, M., MacInnis, D.J. and Park, C.W. (2005), “The ties that bind: measuring the strength of consumers' emotional attachment to brands”, Journal of Consumer Psychology, Vol. 15 No. 1, pp. 77-91.

Tripathi, M.N. (2009), “Customer engagement - Key to successful brand building”, The XIMB Journal of Management, Vol. 6 No. 1, pp. 131-140.

Trusov, M., Bodapati, A.V. and Bucklin, R.E. (2009), “Determining influential users in Internet social network sites”, Journal of Marketing Research, Vol. 47 No. 4, pp. 643658.

Westbrook, R.A. (1987), "Product consumption-based affective responses and postpurchase processes”, Journal of Marketing Research, Vol. 24 August, pp. 258-270.

Wragg, T. (2004), “Nurturing brand advocates”, Brand Strategy, Issue: November, pp. 36-37. 
Table 1. Profile of survey respondents (demographics and Facebook use)

\begin{tabular}{|c|c|}
\hline Category & $\mathrm{N}=265^{*}$ \\
\hline Gender & $\begin{array}{l}26 \%=\text { Male } \\
36 \%=\text { Female } \\
38 \%=\text { did not specify }\end{array}$ \\
\hline $\begin{array}{l}\text { Age } \\
\text { Mode = } 19 \text { years; } \\
\text { Youngest = } 18 \text { years; } \\
\text { Oldest = } 57 \text { years }\end{array}$ & $\begin{aligned} 34 \% & =18-19 \text { years } \\
35 \% & =20-21 \text { years } \\
13 \% & =22-23 \text { years } \\
6 \% & =24-25 \text { years } \\
4 \% & =26-27 \text { years } \\
2 \% & =28-29 \text { years } \\
5 \% & =30 \text { years or older }\end{aligned}$ \\
\hline Nationality & $\begin{aligned} 93 \% & =\text { Irish } \\
4 \% & =\text { Other EU } \\
3 \% & =\text { Outside of EU }\end{aligned}$ \\
\hline Level of Education & $\begin{aligned} 26 \% & =\text { First Year Undergraduate } \\
27 \% & =\text { Second Year Undergraduate } \\
21 \% & =\text { Third Year Undergraduate } \\
5 \% & =\text { Fourth Year Undergraduate } \\
11 \% & =\text { Masters Degree } \\
7 \% & =\text { Doctoral Student }\end{aligned}$ \\
\hline Has a Facebook account, accessed in past month & $100 \%=$ Yes \\
\hline Minutes spent on Facebook on average day & $\begin{aligned} 28 \% & =30 \text { minutes or less } \\
24 \% & =31-60 \text { minutes } \\
8 \% & =61-90 \text { minutes } \\
14 \% & =91-120 \text { minutes } \\
8 \% & =121-180 \text { minutes } \\
18 \% & =\text { More than } 180 \text { minutes }\end{aligned}$ \\
\hline Number of Facebook friends & $\begin{aligned} 4 \% & =50 \text { or less } \\
6 \% & =51-100 \text { friends } \\
7 \% & =101-150 \text { friends } \\
9 \% & =151-200 \text { friends } \\
10 \% & =201-250 \text { friends } \\
12 \% & =251-300 \text { friends } \\
10 \% & =301-350 \text { friends } \\
10 \% & =351-400 \text { friends } \\
6 \% & =401-450 \text { friends } \\
26 \% & =\text { More than } 450 \text { friends }\end{aligned}$ \\
\hline 'Liked' a brand on Facebook in the past year & $65 \%$ = ‘Yes’ \\
\hline
\end{tabular}

* Due to rounding, some figures do not add to $100 \%$. 
Table 2. Summary of hypotheses tests

\begin{tabular}{|c|c|c|c|c|}
\hline \multicolumn{2}{|c|}{ Hypotheses } & \multirow{2}{*}{$\begin{array}{l}\text { Standardised } \beta(\mathrm{t}) \\
0.412^{*}(3.920)\end{array}$} & \multirow{2}{*}{$\begin{array}{l}\text { Expected } \\
+\end{array}$} & \multirow{2}{*}{$\begin{array}{l}\text { Decision } \\
\text { Accepted }\end{array}$} \\
\hline H1a & $\mathrm{SES} \rightarrow \mathrm{BL}$ & & & \\
\hline H1b & $\mathrm{SEI} \rightarrow \mathrm{BL}$ & $0.320 *(3.099)$ & + & Accepted \\
\hline $\mathrm{H} 2 \mathrm{a}$ & $\mathrm{SES} \rightarrow \mathrm{WOM}$ & $0.049(0.484)$ & + & Rejected \\
\hline $\mathrm{H} 2 \mathrm{~b}$ & $\mathrm{SEI} \rightarrow \mathrm{WOM}$ & $0.400 *(3.181)$ & + & Accepted \\
\hline НЗа & $\mathrm{SES} \rightarrow \mathrm{BA}$ & $0.293 *(2.416)$ & + & Accepted \\
\hline H3b & $\mathrm{SEI} \rightarrow \mathrm{BA}$ & $-0.016(-0.116)$ & + & Rejected \\
\hline $\mathrm{H} 4$ & $\mathrm{BL} \rightarrow \mathrm{WOM}$ & $0.309 *(3.796)$ & + & Accepted \\
\hline H5 & $\mathrm{BL} \rightarrow \mathrm{BA}$ & $0.491 *(5.162)$ & + & Accepted \\
\hline
\end{tabular}

$\mathrm{S}-\mathrm{B} \chi^{2}=494.626(220)(\mathrm{p}<0.01) ; \mathrm{NFI}=0.911 ; \mathrm{NNFI}=0.940 ; \mathrm{CFI}=0.948 ;$ IFI $=0.948 ; \mathrm{RMSEA}=0.069$

Note: SES = Self-expressive brand (social self); SEI = Self-expressive brand (inner self); BL= Brand Love;

WOM = Word of mouth; BA $=$ Brand acceptance; $*=p<0.05$. 
Figure 1. Structural model

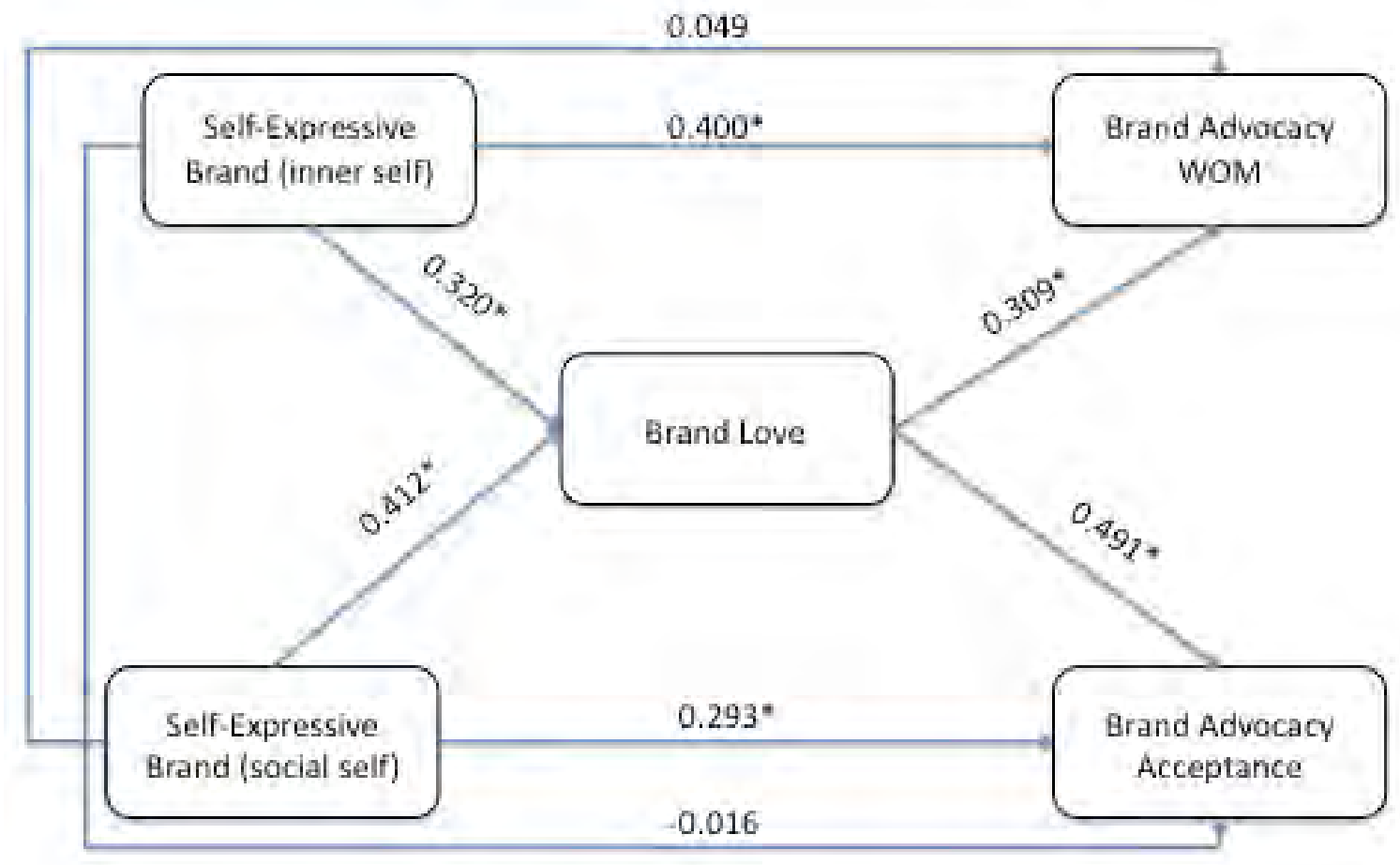

$S-B x^{2}=494.626(220)(p<0.01) ; N F|=0.911 ; N N F|=0.940 ; C F|=0.948 ;| F \mid=0.948 ; R M S E A=0.069$ * * pe0.05. 


\section{Appendix I. Scale items and measurement model results}

\begin{tabular}{|c|c|c|c|}
\hline Constructs and scale items & Factor loadings & $\mathbf{C R}$ & AVE \\
\hline \multicolumn{4}{|l|}{ Self-expressive brand } \\
\hline \multicolumn{4}{|l|}{ - Inner self } \\
\hline This brand symbolises the kind of person I really am inside & 0.913 & 0.955 & 0.842 \\
\hline This brand reflects my personality & 0.896 & & \\
\hline This brand is an extension of my inner self & 0.923 & & \\
\hline This brand mirrors the real me & 0.937 & & \\
\hline \multicolumn{4}{|l|}{ - Social self } \\
\hline \multirow{4}{*}{$\begin{array}{l}\text { This brand contributes to my image } \\
\text { This brand adds to the social "role” I play } \\
\text { This brand has a positive impact on what others think of me } \\
\text { This brand improves the way society views me }\end{array}$} & 0.860 & 0.938 & 0.790 \\
\hline & 0.887 & & \\
\hline & 0.929 & & \\
\hline & 0.877 & & \\
\hline Brand love & & & \\
\hline $\begin{array}{l}\text { This is a wonderful brand } \\
\text { This brand makes me feel good }\end{array}$ & 0.857 & 0.963 & 0.766 \\
\hline This brand makes me feel good & 0.917 & & \\
\hline This brand is totally awesome & 0.917 & & \\
\hline I have neutral feelings about this brand $(r)^{*}$ & - & & \\
\hline This brand makes me very happy & 0.875 & & \\
\hline I love this brand! & 0.898 & & \\
\hline I have no particular feelings about this brand $(\mathrm{r})^{*}$ & - & & \\
\hline This brand is a pure delight & 0.884 & & \\
\hline I am passionate about this brand & 0.845 & & \\
\hline I am very attached to this brand & 0.802 & & \\
\hline Brand advocacy & & & \\
\hline \multicolumn{4}{|l|}{ - Word of mouth } \\
\hline $\begin{array}{l}\text { I click 'like' for this brand in order to talk up the brand to my } \\
\text { friends }\end{array}$ & 0.824 & 0.895 & 0.633 \\
\hline I click 'like for this brand as it enhances my Facebook profile & 0.666 & & \\
\hline \multirow{2}{*}{$\begin{array}{l}\text { I click 'like' for this brand in order to spread the good word about } \\
\text { this brand }\end{array}$} & 0.847 & & \\
\hline & \multicolumn{3}{|c|}{ I give this brand a lot of positive word-of-mouth online } \\
\hline I recommend this brand to friends and family on Facebook & 0.774 & & \\
\hline \multicolumn{4}{|l|}{ - Brand acceptance } \\
\hline \multirow{2}{*}{$\begin{array}{l}\text { I would like to try new products introduced under this brand name } \\
\text { If the maker of this brand did something I didn't like I would be } \\
\text { willing to give it another chance }\end{array}$} & 0.800 & 0.718 & 0.561 \\
\hline & 0.694 & & \\
\hline \multicolumn{4}{|l|}{$\begin{array}{ll} & \text { Fit indices } \\
\end{array}$} \\
\hline $\begin{array}{cc}\mathrm{S}-\mathrm{B} \chi^{2}=494.591(220)(\mathrm{p}<0.01) & \mathrm{CFI}=0.948 \\
\text { RMSEA }=0.069 & \mathrm{IFI}=0.948\end{array}$ & $\begin{array}{c}\mathrm{NFI}=0.911 \\
\mathrm{NNFI}=0.940\end{array}$ & & \\
\hline
\end{tabular}

Note: ${ }^{*}$ Item deleted in the validation process. CR: Composite Reliability; AVE: Average Variance Extracted. 
Appendix II. Descriptive Statistics and Correlations

\begin{tabular}{|l|ccccccc|}
\hline & Mean & SD & $\mathbf{1}$ & $\mathbf{2}$ & $\mathbf{3}$ & $\mathbf{4}$ & $\mathbf{5}$ \\
\hline 1. Self-expressive brand (inner self) & 2.52 & 1.14 & .842 & & & & \\
2. Self-expressive brand (social self) & 2.66 & 1.15 & .624 & .790 & & & \\
3. Brand love & 3.22 & 1.04 & .417 & .442 & .766 & & \\
4. Brand advocacy (worth of mouth) & 2.32 & 1.01 & .407 & .325 & .360 & .633 & \\
5. Brand advocacy (brand acceptance) & 3.02 & 1.09 & .283 & .367 & .456 & .429 & .561 \\
\hline
\end{tabular}

Note: Means and standard deviations are based on summated scale averages. Items deleted in the validation process are not included. Squared correlations are below the diagonal and AVE estimates are presented on the diagonal. 